\title{
Arkadiusz ŻUKOWSKI
}

Warmia and Mazury University in Olsztyn, Poland

arkadiusz.zukowski@uwm.edu.pl

\section{THE UNION OF SOUTH AFRICA TOWARDS THE OUTBREAK OF THE SECOND WORLD WAR}

ABSTRACT At the outbreak of the Second World War the Union of South Africa was military unprepared and divided politically. The division into supporters and opponents of the war against Germany was clear, both in the Parliament, as well as in South African society, particularly among large parts of the Afrikaners it manifested itself as significant political support and public acceptance of the ideology of Adolf Hitler and the Third Reich. The moderate Afrikaners and first of all the English-speaking population supported joining the war on the side of the Allies. In the parliament, the issue has led to a government crisis. The Union of South Africa as a British Dominion finally declared war on Nazi Germany. In a relatively short time the state was able to prepare its institutions, society and economy for participation in the war. An important role in the consolidation of the political elite and society in the fight against Nazi Germany on the side of to the Allies was played J. C. Smuts.

Keywords: Union of South Africa, Second World War, the Allies, Afrikaners, Jan C. Smuts 
T he Union of South Africa, called in Poland, in the interwar period and during the Second World War, "the Southafrican Union" (Unia Południowoafrykańska) or the South-African Union (Unia Południowo-Afrykańska), and after 1945 the Union of South Africa (Związek Poludniowej Afryki) constituted on the African continent an exceptional state system with a specific history and ethno-racial, socio-economic and political structures.

The genesis of the Union of South Africa is related to the events of the late nineteenth and the turn of the twentieth century. After the Anglo-Boer War (1899-1902) and the after the signing of the Peace Treaty in Vereeniging on 31 May 1902 negotiations about the mitigation of Anglo-Boer antagonisms and legislative work on the creation of one state organism from the following entities of the British colonies: Cape Colony and Natal, and two former Boer republics (after 1902 also British colonies): the Orange Free State and the South African Republic (Transvaal) were launched.

In 1909 the British House of Commons passed a law on South Africa (South Africa Act of 1909), which was a constitutional basis for the functioning of the newly formed state. In 1910 a unification of the two British colonies and the two Boer republics seized by Great Britain was brought about. The Union of South Africa was set up and received the status of a British dominion (similar to Canada, Australia and New Zealand $)^{1}$.

According to the census of 1911, the Union of South Africa had a population of $5,973,394$ people $^{2}$. Whites were about 1.3 million inhabitants, most of whom was represented by Afrikaners; Africans were about 4 million, Coloureds about 0.5 million, and Asians about 180 thousand $^{3}$.

Within the white population (Whites) people of European origin (including non-European countries, among others from the United States, Canada, Australia, New Zealand) are classified. Among Whites, as it was mentioned earlier, prevailed Afrikaners who until 1910 were called the Boers. Coloureds constituted "persons of mixed blood", derived mainly from the sexual interactions between the white population, Africans and descendants of San people (Bushmen) and Khoikhoi (Hottentots). Asians were called "Natives coming from Asia and their descendants, mostly Hindus". In contrast, the term "black Africans" was used to refer to all groups of Bantu peoples, while it should be mentioned that in the past Whites used to describe the group with other terms $s^{4}$.

For more information see: L.M. Thompson, The Unification of South Africa 1902-1910, Oxford 1960.

2 W.L. Thorp, H.E. Thorp, 'The Annals of South Africa' in W.L.Thorp (ed.), The Business Annals, New York 1926, p. 308, at <http://www.nber.org/chapters/c4650.pdf>, 10 August 2015.

3 'Boer War: 1899-1902' in History of South Africa, History World, at <http://www.historyworld.net/ wrldhis/PlainTextHistories.asp?ParagraphID=oui\#ixzz3iOp9p5gd>, 8 August 2015.

4 Since the days of the Portuguese exploration of Southern Africa, Africans were called contemptuously "Kaffirs". In 1910, the authorities of the Union of South Africa have put in relation to them official term "Natives", while maintaining the functioning of the deadline less official term as "black Africans". 
In the Union of South Africa full political rights belonged only to Whites, while despite the efforts of Great Britain and the moderate attitude of Afrikaners towards the British, Afrikaans isolationism and nationalism have not expired, nor ended with the Afrikaners' struggle for independence from the British government. Although the first Prime Minister of the Union of South Africa was the Boer General Louis Botha (Prime Minister in the years 1910-1919), in fact political and especially economic power in the country was in the hands of the English-speaking citizens, particularly of British origin. The next Prime Minister of the Union who also sought a compromise with Great Britain was Gen. Jan Christiaan Smuts (Prime Minister in the years 1919-1924).

The reluctant mood among Afrikaners to the British grew, especially due to the fact that among them a rapid pauperization and social downgrade took place. This group was called "poor Whites" and in the initial period consisted of $10 \%$, and later in the 30 s more than $50 \%$ of the entire settlement community of European origin (mainly Afrikaners) $)^{5}$. The discontent of thousands of white workers in Transvaal mining centers turned into an armed uprising, the so-called "Red Revolt", in March 1922, which was supported by the communists. The government of Gen. J. C. Smuts used against them, outside the police, artillery, bombers and infantry.

It should be emphasized that Afrikaners were very receptive to nationalist slogans and strongly supported the National Party, which was founded by James Barry Munnik Hertzog in 1914 ${ }^{7}$. It only defended their interests. It supported racial segregation and was in opposition to the British rules in South Africa (British imperialism). In the future, the party would politically unite Afrikaners and lead to the establishment of a fully independent state for them.

The British authorities had to yield to the pressure of Afrikaner nationalists by expanding the autonomy of the dominion and introducing the right to satisfy their aspirations (the proper flag of South Africa, the second official language - Afrikaans, education, proper political parties and social associations) ${ }^{8}$. In accordance with the Balfour Declaration of 1926 the Union acquired the legal equality with Great Britain as a part of the British Commonwealth of Nations. From that moment the South African government had a formal right to advise the British King on the nomination of the Governor-General. In 1931, the British Parliament adopted the so-called "Westminster statute" under which the Union of South Africa granted full political independ-

The last term emphasized that to the group of Africans also another racial group belonged, namely "white Africans" - a term attributed primarily to Afrikaners. In 1940 the term "Natives" was replaced with the term "Bantu". In the early 80 s it was considered that the term "Bantu" was offensive to the native people of Africa and the term "Africans" which is applicable to today's state of affairs was introduced.

5 L. de Villiers, J. Marais, N. Wiehahn (eds.), Doing Business with South Africa, New Canaan 1984, p. 16.

6 For more information see: N. Herd, 1922. The Revolt on the Rand, Johannesburg 1966.

7 J.B.M. Hertzog led the party in the years 1914-1934. See more: C.M. van den Heever, General J.B.M. Hertzog, Johannesburg 1946.

8 W. Grütter, D.J. van Zyl, The History of South Africa, Cape Town 1981, p. 51. 
ence. Three years later, the statute was adopted by the South African parliament ${ }^{9}$. The British Government was represented in the Union by the High Commissioner. The Governor-General was already appointed by the South African government (formerly by the British King) and was representing not the British government, but the person of the British king.

Dissatisfaction of a large part of the Afrikaners caused that the parliamentary election in 1924 was won the National Party, in coalition with the Labour Party (LP). The rule of Prime Minister J. B. M. Hertzog, lasting from 1924 until 1939, recognized as a basis for its internal activities the separation of the races with preferential political, economic, social and cultural treatment of Whites ${ }^{10}$. Afrikaners' supremacy among white citizens of the Union arose ${ }^{11}$.

In 1933 the National Party, under the leadership of J. B. M. Hertzog, in order to continue to rule created an alliance with the more moderate political party of J. C. Smuts - the South African Party (SAP). A year later there was a merger of the two parties and the founding of the United South African National Party (USANP), whose leader was J. B. M. Hertzog. Some members of the former National Party thought that entering into an alliance with the British and South African liberal Afrikaners was an excessive compromise which reconciled the interests of the Afrikaner nation. Therefore, under the leadership of Dr. Daniel François Malan a new political party was brought to life under the telling name the Purified National Party (PNP).

In the parliamentary election in 1938, again, the USANP achieved a sweeping victory (111 seats in the 150 -seat Parliament). The remaining seats were granted to: the PNP -27 , the Dominion Party (DP) $-8, \mathrm{LP}-3$ and the Socialist Party (SP) $-1^{12}$.

The attack of Nazi Germany on Poland on 1st September 1939, but first at all the declaration of war of Great Britain on Nazi Germany, two days later the Germans' declaration of war against Great Britain, led to a government crisis in the Union of South Africa $^{13}$.

On the first day of the war the South African Foreign Ministry refrained from an official response ${ }^{14}$. The Minister of Defence, Oswald Pirow ${ }^{15}$ behaved in the same way. Moreover, at the session of Parliament on 2 September Prime Minister James Barry

9 E.A. Walker, A History of Southern Africa, London 1959, pp. 636-637.

10 See more: M. Horrel, Legislation and Race Relations. A Summary of the Main South African Laws which Affect Race Relationships, Johannesburg 1971.

11 See more: L.E. Neame, General Hertzog. Prime Minister of the Union of South Africa since 1924, London 1930.

12 South Africa 1982. Official Yearbook of the Republic of South Africa, Cape Town 1983, pp. 174, 176.

13 'Grave Crisis in Union Cabinet', The Cape Argus, 4 September 1939.

14 'Pretoria Kalm', Die Vaderland (Spesiale Uitgaaf), 1 September 1939.

15 'Pirow Can Say Nothing', The Sunday Times (Special Ed.), 3 September 1939, p. 1. 
Munnik Hertzog did not want to speak about the war that started, and the matter was not on the agenda ${ }^{16}$. On the same day, however, J. B. M. Hertzog convened a meeting of the government and appealed to its members to opt for the so-called "qualified neutrality", also known as the so-called "semi-neutrality"17. He considered the arrangements for the neutrality of the Union of South Africa, announced by his government during a visit to Neville Chamberlain in Munich in 1938, as binding. According to J. B. M. Hertzog, the actions of Adolf Hitler were nothing more than the liberation of Germany from the shackles of the Treaty of Versailles. According to gen. J. C. G. Kemp, who supported J. B. M. Hertzog, participation in the war in Europe could lead South Africa to a bloodbath ${ }^{18}$. This would divide the white community of the Union into two antagonized camps.

J. B. M. Hertzog received the support from O. Pirow and N. C. Havenga and three other ministers, while J. C. Smuts, together with six ministers, demanded the entry of the Union to the war ${ }^{19}$. The problem of neutrality, or active participation in the war divided the government into two parts. J. B. M. Hertzog convened the next meeting of the government on 3rd September only to announce that the proposed motion on neutrality will be submitted in the Parliament ${ }^{20}$. He was convinced that he would obtain the necessary parliamentarian majority. That day the ultimatum of Great Britain urging Germany to withdraw its troops from Polish territory expired - Great Britain declared war on Germany.

On 4th September the most dramatic parliamentary debate in the history of the Union of South Africa was held, during which J. B. M. Hertzog tried to win support for the concept of neutrality. He claimed that every sovereign state has the right to remain neutral if it is required by the raison d'état, and gave the example of the Irish government's decision. He believed that the Union of South Africa should not take part in the war that broke out in Europe. He also stated that the Union was not interested in

16 For D.F. Malan the interpellation concerning an attitude of the Union government on started the war, Prime Minister J.B.M. Hertzog answered that this issue will be discussed by the Parliament on 4 September1939. See: J.L. Basson, J.G. Strijdom. Sy politieke loopbaan van 1929 to 1948, Pretoria 1980, p. 259.

17 The so-called "qualified neutrality" or "semi-neutrality" formulated by the J.B.M. Hertzog government in 1938, had to rely that the Union of South Africa would remain neutral, by fulfilling a number of conditions: e.g. allowing the use of Great Britain from its base at Simonstown near Cape Town and South African seaports and the fulfillment of certain obligations resulted from the membership in the British Commonwealth of Nations and the League of Nations.

18 J.J. Breitenbach (ed.), South Africa in the Modern World (1910-1970). A Contemporary History, Pietermaritzburg 1974, p. 388; B. Friedman, Smuts. A Reappraisal, Johannesburg 1975, p. 145.

19 For neutrality were (J.B.M. Hertzog, N.C. Havenga, O. Pirow, J.C.G. Kemp, A.P.J. Fourie and H.A. Fagan), and joining the war against Germany supported (J.C. Smuts, D. Reitz, C.F. Clarkson, R. Stuttaford, H.G. Lawrence, W.R. Collins and R.H. Henderson). See: J. H. van Le Roux, P.W.Coetzer, A.H. Marais (eds.), Generaal J.B.M. Hertzog. Sy strewe en stryd, Johannesburg 1987, p. 661. In biography of J.C. Smuts written by F.S. Crafford mistakenly is stated that the voting was held on 3 September 1939. Cf: F.S. Crafford, Jan Smuts. A Biography, New York 1943, p. 281. 
the war between Poland and Germany, and England has some obligations to Poland, contrary to the Union which did not have such obligations ${ }^{21}$. The official relations of the neutral Union with the states which entered the war would remain unchanged. He partly blamed Great Britain that before the announcement of the state of war with Germany did not request an inquiry into the Union, whether the Union is prepared to participate in $\mathrm{it}^{22}$. The concept of neutrality of J. B. M. Hertzog supported the minority group of politicians from the former National Party.

In his speech J. B. M. Hertzog, however, was not focused completely on defending the concept of neutrality, but also justified partly Adolf Hitler ${ }^{23}$. Even he showed him sympathy and understanding ("I sympathize with Hitler, I know how he feels. I, too, have been downtrodden") ${ }^{24}$. He interpreted the invasion of German troops into the demilitarized zone of the Rhineland, the annexation of Austria, Czechoslovakia and aggression against Poland as actions that are a compensation for the harm inflicted on Germany by the Treaty of Versailles. He compared the efforts of Adolf Hitler in the pursuit of freedom for Germany with its own struggle for freedom for the Afrikan$\mathrm{ers}^{25}$. This position was supported by D. F. Malan, who even interpreted the occupation of Czechoslovakia by Germany as action related to ensure its own security ("matter of safety" $)^{26}$.

J. C. Smuts, who represented an opposite attitude, declared that Adolf Hitler wanted to dominate the world and after the demands of receipt of Gdańsk he would demand the return of former German colonies, including South-West Africa, administered by the Union of South Africa. He also pointed to the Union's commitment to Great Britain and the British Commonwealth of Nations. He considered the breaking off of the relations with Germany to be in accordance with the interests of the South African state ${ }^{27}$. Moreover, he also warned that not opting in the war on the side of the Allies could lead in the future to the isolation of South Africa surrounded by a hostile international environment.

The South African parliament passed by a vote of 80 to 67 the entry of the Union of South Africa into the war against Germany ${ }^{28}$. The English newspapers conducive to

21 J.C. Smuts Jr, Jan Christian Smuts. A Biography, Cape Town 1952, p. 375.

22 R.E. Gordon, C.J. Talbot (eds.), From Dias to Vorster. Source Material on South African History 1488-1975, Cape Town 1977, p. 405.

23 According to J.C. Smuts statement of J.M.B. Hertzog was a complete justification of the actions of Hitler, See: 'Premier for Neutrality. Gen. Smuts's Challenge', The Cape Argus, 4 September 1939.

24 R. Citino, Germany and the Union of South Africa in the Nazi Period, New York 1991, p. 225 (Contributions to the Study of World History, 27).

25 A.W. Stadler, 'The Period 1939 to 1948 ' in T. Cameron, S.B. Spies (eds.), An Illustrated History of South Africa, Cape Town 1988, p. 260.

26 B. Friedman, Smuts..., p. 151.

27 J. Crwys-Williams, A Country at War, 1939-1945. The Mood of a Nation, Rivonia 1992, p. 21 (South Africans at War, 10).

28 J. Liebenberg, 'Hertzog in Power, 1924-1939' in C.F.J. Muller (ed.), 500 Years. A History of South Africa, Pretoria 1988, p. 441. 
J. C. Smuts even wrote that the Parliament rejected the "policy of friendship with Germany of Gen. Hertzog" ${ }^{29}$. It seems that a significant effect on Parliament's decision had an argument about the possibility of losing South-West Africa, which was considered not only as a zone of its influence, but almost as an integral part of the state.

Prime Minister J. B. M. Hertzog, facing the lack of support from the members of the government and the Parliament, tried to push through the concept of neutrality by asking the Governor-General Patrick Duncan for the dissolution of the Parliament and a call for a new election ${ }^{30}$. The Governor-General as an opponent of foreign policy of N. Chamberlain issued a negative decision. J. B. M. Hertzog, at that time, had to resign and the Governor-General's task of forming a new government was entrusted to the current minister J. C. Smuts. He set up a coalition government with the USANP members and MPs from LP and DP who were loyal to him.

J. C. Smuts headed the South African Government for the entire period of the Second World War. At the same time he held the post of the Minister of Defence and the Supreme Commander of the Union Defence Force ${ }^{31}$. Moreover, as in the case of Prime Minister J. B. M. Hertzog, he held personal sovereignty over the South African Ministry of Foreign Affairs, which meant its dominant influence on the South African foreign policy.

J. C. Smuts had a high position among the Western allies, especially among the political establishment in Great Britain. He had a very good relationship with Winston Churchill. He served as a full member of the British War Cabinet. Even during the absence of W. Churchill in London he passed chairmanship of the War Cabinet to J. C. Smuts. At the time, Edward Raczyński (Polish Ambassador in London and Minister of Foreign Affairs) wrote the following about J. C. Smuts: "This is a personage with whom everybody reckons with during imperial conferences, he is reliable and influential, surrounded by English prostration, which he indeed reciprocates" 32. In September 1941 he was appointed the Field Marshal of the British Army ${ }^{33}$.

The Union of South Africa joined the Second World War on the side of the Allied forces on 6 September $1939^{34}$ (On 27 January 1943 the Parliament, at the request of the South African J. C. Smuts, agreed to send troops to Europe). The Parliament at the request of J. C. Smuts did stipulate that the South African army would never be used

29 'Gen. Smuts Becomes Prime Minister Today', The Cape Times, 5 September 1939.

30 K. Ingham, Jan Christiaan Smuts. The Conscience of a South African, London 1986, p. 205.

31 J. Liebenberg, 'Hertzog in Power...', p. 441.

32 E. Raczyński, $W$ sojuszniczym Londynie. Dziennik ambasadora Edwarda Raczyńskiego 1939-1945, Londyn 1974, p. 207.

33 J.J. Breitenbach (ed.), South Africa in the Modern World..., p. 386; D.W. Krüger, The Making of a Nation. A History of the Union of South Africa. 1910-1961, Johannesburg-London 1969, p. 224.

34 Mieczysław Nurek reported that the Union of South Africa went to war after the imposed reorganization of the government [...]. See: M. Nurek, Polska w polityce Wielkiej Brytanii w latach 1936-1941, Warszawa 1983, p. 251. In fact, the decision of the South African Parliament was sovereign: Great Britain had never exercised pressure on the Union to declare war. See: D. W. Krüger, The Making of a Nation..., p. 201. 
outside the African continent ${ }^{35}$. In connection with the state of war between the Union and Germany the staff of the German Embassy and consulates in the Union of South Africa had to return to Germany, and the staff of the South African Embassy in Berlin was evacuated to Sweden, where they strengthened the Embassy personnel in Stockholm ${ }^{36}$.

In principle, the position of Government of the Union of South Africa on the entry to the war and the related subsequent diplomatic steps were no different from the attitude of other Allies, especially the British dominions ${ }^{37}$. Severance of diplomatic relations with the allies of Germany took place simultaneously with the decisions of Great Britain or within the span of a few days or a few month $s^{38}$. These activities resulted primarily from commitments to the Allies, and occasionally from other reasons. One such example was the severance of diplomatic relations with Vichy, which took place on 23 April 1942, almost two years after the decision of Great Britain ( 5 July 1940). The Union did not recognize the government of Free France of Charles A. de Gaulle ${ }^{39}$. But the main determinant was the proximity of Madagascar administered by the Vichy government, and since 1942 the threat of seizure of the island by the Japanese and from there to make the invasion of South Africa.

Although the Union of South Africa, after the outbreak of the Second World War, became an ally of the Allies, it referred to the Polish case initially with reserve and distance. The South African authorities were interested mainly in the consequences of the war for the fate of Europe, and indirectly for the Union. J. C. Smuts wrote on 21 September 1939 about the spectacular and very rapid collapse of Poland, which negatively affected the situation of the Allies. Therefore he expected from the opponents who criticized the involvement of the Union of South Africa in the conflict in Europe answers to difficult questions such as why the Union should fight for the state, which was so weak and why sacrifice millions of lives and expose civilization for the risk of resurrecting Poland? ${ }^{40}$.

The war which broke out on 1 September 1939 was treated as a war primarily against Great Britain. The Union's entry to the war was not associated directly with

35 'Historic Sitting of Parliament', The Cape Times, 5 September 1939.

36 State Archives - Pretoria, BTS, PM 4/2/2, Vol. 1.

37 Apart from the Union of South Africa war against Germany declared the following British dominions (3 September - Australia, New Zealand; 10 September - Canada). On behalf of India, on 3 September war was declared by the British government. The only exception was Ireland, which announced neutrality on 3rd September.

38 The Union of South Africa during the Second World War broke off diplomatic relations with: Italy (11 June 1940), Finland (8 December 1941), Japan (8 December 1941), Romania (8 December 1941), Hungary (8 December 1941), Bulgaria (13 December 1941), Siam (now Thailand) (25 January 1942) and Vichy (23 April 1942).

39 The Union of South Africa recognized the government led by Charles de Gaulle (Provisional Government of the French Republic) only in June 1944. See: R. MacNab, The Story of South Africa House. South Africa in Britain, the Changing Pattern, Johannesburg 1983, p. 128.

40 W.K. Hancock, J. van der Poel (eds.), Selections from the Smuts Papers, Vol. 6, Cambridge 1973, p. 193. 
Poland but was more likely an attempt at maintaining one's own independence. According to J. C. Smuts, it was not a matter of Gdańsk and Poland. The honor and freedom of South Africa was at stake $e^{41}$.

The Union of South Africa's entry to the war on Britain's side resulted in a split in the heretofore ruling USANP. In protest, in 1940 the right wing of the party, together with the PNP, formed a new political party - the Re-United National Party (RNP) under the leadership of D. F. Malan. On the other hand, J. B. M. Hertzog founded the Afrikaner Party $(\mathrm{AP})^{42}$.

The case for further participation of the Union of South Africa in the war was the subject of parliamentary debates and the public speeches. The newly formed South African government tried to convince the society and the opposition about the validity of the recent decision of the Parliament. The biggest propaganda effect is attributed to J. C. Smuts's speech in Bloemfontein on 3 November 1939 in which he widely expounded the rights for participating in the fight against A. Hitler ${ }^{43}$. In his opinion, if Germany won the war then not only England, but also South Africa would lose. First, the state will become a Nazi-state, and later lose its independence ${ }^{44}$.

It is worth to mention that during the war J. C. Smuts favorably referred to Poland and its armed struggle. For example, during the meeting with the delegation of the Polish Armed Forces in Pretoria in September 1942 he stated: "You are the first and the best among all the Allies. I know you and love you even since the fighting shoulder to shoulder with the armed forces of South Africa, and especially with the our 1st division" ${ }^{5}$. Words of support for fighting Poland J. C. Smuts were expressed particularly during the Warsaw Uprising ${ }^{46}$. He also perceived the importance and complexity of the Polish case, especially in the context of Polish-Soviet relations. According to him, the Polish question was at this moment the most important but most difficult among those which absorbed the attention of the superpowers" ${ }^{\prime 7}$.

On the other hand, Afrikaner nationalists associated with J. B. M. Hertzog and D. F. Malan during the first years of the war, when Adolf Hitler achieved spectacular victories, submitted (four times) to the Parliament proposals for ending the war with Germany and to conclude a separate peace agreement with them. Already on 23 January 1940 J. B. M. Hertzog presented such a proposal, arguing, as it was on 4 September 1939, that the war was not a matter of the Union of South Africa and that it was drawn in connection with the decision of the Great Britain. According to him, Germany's

41 J.C. Smuts, Greater South Africa. Plans for a Better World; Speeches, Johannesburg 1940, p. 118.

42 A.W. Stadler, 'The Period 1939 to 1948', pp. 260-270.

43 J.C. Smuts, Greater South Africa..., pp. 107-119.

$44 \quad$ Ibid., p. 118.

45 A. Idzik, Czterdziestolecie 20-ego Putku Piechoty Ziemi Krakowskiej, 1919-1959, Londyn 1959, p. 103.

46 A. Żukowski, 'Afryka Południowa a Powstanie Warszawskie' in M.M. Drozdowski (ed.), Powstanie Warszawskie z perspektywy pótwiecza, Warszawa 1995, pp. 263-264.

47 R. Kraus, Old Master. The Life of Jan Christian Smuts, New York 1944, p. 410. 
goal was not domination over other nations, but equality by repairing the harms done to the Germans by the "shameful" Treaty of Versailles ${ }^{48}$. He added that after the campaign in Poland, Adolf Hitler offered peace to the Western Powers, and its rejection he considered a mistake. He claimed that the continuation of the war against Germany is commission of a crime, that the Union of South Africa should not have anything to do with it ${ }^{49}$. In sum, J. B. M. Hertzog in the South African Parliament, submitted the request three times to conclude a separate peace with Germany, and D. F. Malan made such a request once.

After the occupation of France by Germany, in June 1940, and especially after the German attack on the USSR on 22 June 1941, opposition MPs joined a strong attack on the government of J. C. Smuts. In the parliamentarian debates the opposition attacked especially J. C. Smuts for the "involvement" of the Union of South Africa in the war. In June 1940, they called for his resignation and surrender to the Germans ${ }^{50}$. D. F. Malan called to form a government on the model of the government of Vidkun Quisling in Norway. He argued that Germany wants such a government in South Africa, which would have a friendly attitude towards to them. "We can create such a government of the people that have already shown that they are not hostile to Germany"s1. Statements were expressed that the Union was fighting in the war in the name of "Jewish Imperial Capitalism" ${ }^{52}$. Soon, they accused the Government of supporting communism. Jan Christiaan Smuts came to be known as a comrade of Joseph Stalin and the man who tolerates the spread of the communist propaganda ${ }^{53}$. In sum, the content and conclusions of the motions of the opposition regarding the withdrawal of the Union of South Africa from the war were similar as in the first case one of these motions was rejected by the Parliament.

At the outbreak of the Second World War, the South African Parliament was a reflection of the divisions among the white population, because only white people of this state had political rights and parliamentary representation.

The English-speaking group considered its duty to support the Great Britain in the war. While the vast majority of Afrikaners had a different opinion about this issue. Many of them openly spoke out against the pro-British attitude of the authorities in Pretoria. The second half of the 30 s and beginning of the 40 s was a period of strengthening nationalist slogans among Afrikaners, as well as the beginning of the formation of the movements fascinated with Fascist ideology, which, because of its racial stratification, met with favourable conditions.

48 W.K. Hancock, Smuts. The Fields of Force 1919-1950, Cambridge 1968, p. 337.

49 Ibid. The vote on this motion took place on 27 January 1940 (67 votes "for" and 80 votes "against").

50 B. Williams, Botha, Smuts and South Africa, London 1946, pp. 158-159 ("Teach Yourself History" Library).

$51 \quad$ R. Kraus, Old Master..., p. 409.

52 H.B. Thom, D.F. Malan, Kaapstadt 1980, pp. 140-144.

53 E.H. Louw, The Communist Danger, Cape Town 1940, p. 17 (Publications of the Enlightenment Service of the Reunited Nationalist Party, 5). 
After the declaration of war on Germany, there was a threat of an anti-government revolt similar to that after the entry of the Union of South Africa to the First World War on the side of the Allies (the Union military effort was significant - out of 136,000 white volunteer soldiers on fronts - including France, Flanders, Tanganyika - 76,000 soldiers fought ${ }^{54}$. Then some Afrikaners Generals openly revolted against the Great Britain ${ }^{55}$. Gen. Solomon Maritz went with the army over to Germany in South West Africa (now Namibia). He was supported by the well-known generals who were respected due to their achievements in the Anglo-Boer War (1899-1902): Jacobus Hercules de la Rey, Jan Christoffel Greyling Kemp and Christian Frederick Beyers.

They saw the future of the Afrikaner nationalism, whose aim was to establish its own independent republic, in the victory of Germany in the war ${ }^{56}$. In August 1941 when the total defeat of the Soviet Union seemed inevitable, future Prime Minister Hendrik Verwoerd of the South Africa Afrikaans compared the "Christian nationalism" to Nazism ${ }^{57}$. During this time, pro-Nazi organizations gained significance ${ }^{58}$, acting officially (including Ossewa Brandwag) or in a clandestine manner (e.g. Nuwe Orde, $<$ New Order $>$ and Grys Hemps < Grey Shirts $>$ ), for example, Ossewa Brandwag had in 1941 about 300-400,000 members organized paramilitary fighting squads ${ }^{59}$. They conducted a propaganda campaign, practiced spying for Germany and engaged in numerous acts of sabotage.

The South African government decided not to outlaw them, but interned their leaders and banned the public display of Nazi symbols. Also the Government introduced the death penalty for sabotage.

Afrikaner nationalists, proponents of Adolf Hitler, celebrated every victory of the German troops, for example, the "Supporters of Malan, Pirow and van Rensburg celebrated the fall of France in 1940 as a national holiday" ${ }^{\circ}$. Each of their defeats was for them a day of mourning.

Non-whites, i.e. Africans, and to a lesser extent, Coloureds and Asians or as a matter of fact their organizations cherished the hope that the anti-Nazi attitude of the authorities in September 1939 would be a beginning of a process aimed at the democratization of political, social and economic life. Overall, non-whites, especially Africans supported the participation of the Union of South Africa in the war against Germany. However, the part of the Coloureds from the Cape Province sympathized with the Japanese. Others, however, fought as soldiers of so-called “The Cape Corps" against the Axis.

\footnotetext{
54 E.A. Walker, A History of South Africa, London 1965, p. 565.

55 See more: G.D. Scholtz, Die Rebellie 1914-1915, Johannesburg 1942.

56 Die Transvaler, 6 November 1940.

57 A. Hepple, Political Leaders of the Twentieth Century. Verwoerd, Harmondsworth 1967, p. 212 (Pelican Book, A913).

58 M.J. Malinowski, Republika Potudniowej Afryki. Przemiany wewnętrzne i ich międzynarodowe uwarunkowania, Warszawa 1988, pp. 38-39.

59 A.W. Stadler, 'The Period 1939 to 1948', p. 262.

60 J. Balicki, Historia Burów. Geneza państwa apartheidu, Wrocław 1980, p. 210.
} 
The activity and the commonness of pro-Nazi organizations was a source of political embarrassment of most local left-wing parties, which manifested a negative attitude towards the participation of the Union of South Africa in the war. In these parties there were divisions and instances of misunderstanding. At the beginning of September 1939 the Communist Party of South Africa (CPSA) released a short statement ("What is the War About"), in which, among others, it wrote about the struggle of Poland to maintain freedom ${ }^{61}$. However, at the annual party conference in March 1940 they condemned this statement and called for the fight against the Union's involvement in the war. For this purpose, even the use of the pro-Nazi Afrikaner workers was planned. In contrast, the African National Congress (ANC) in December 1939, under certain conditions, and soon unconditionally supported the government of J. C. Smuts. The change of optics, of almost all left-wing parties, concerning the relation to the participation of the Union of South Africa in the war, took place after the German invasion of the Soviet Union. Then a nationwide campaign of the "defence of South Africa" began. However, deep divisions, particularly among Whites remained. It testified, among other things, to the changes in the South African political scene and the results of parliamentary election in 1943. It is claimed that J. C. Smuts had to fight in the war on two fronts, one against the Axis, and the second against internal opposition ${ }^{62}$.

The Union of South Africa was totally unprepared for the initiation of military actions. Even before the outbreak of the Second World War, the then Minister of Defence, O. Pirow stated that the South African army would need at least six months to reach combat readi$n^{n e s s^{63}}$. For J. C. Smuts, that term was too distant and he believed that the Union should be ready for combat immediately after joining the war. In September 1939 the South African army had just over 5,000 soldiers ${ }^{64}$, of which only 260 were officers. The staff of the South African Armed Forces at the beginning of September 1939 was as follows: the Army 3,548 troops, aviation $-1,837$, the Navy -432 , civil defence $-11,421$. At that time, the South African army had only six modern aircrafts and did not have any warships ${ }^{65}$.

The South African army formed for the purpose of the war, in connection with the internal situation, was voluntary in nature. It was reported that more than 2 million volunteers, including 120,000 Africans joined the $\operatorname{army}^{66}$. In a short period of time the size of the army considerably increased ${ }^{67}$.

61 B. Hirson, Yours for the Union. Class and Community. Struggles in South Africa 1930-1947, Johannesburg 1989, p. 79.

62 P. Meiring, Smuts..., p. 150.

63 Ibid., p. 145.

64 See: W. Grütter, D.J. van Zyl, The History..., p. 52.

65 A. Gąsowski, RPA, Warszawa 2006, p. 133 (Historia Państw Świata w XX Wieku).

66 Ibid.

67 J. Liebenberg, 'Smuts in Power, 1939-1948', in C.F.J. Muller (ed.), 500 Years..., p. 443. 
The South African army took part in the fighting, inter alia, in East Africa (July 1940-November 1941) - the battle against Italian troops in Somalia and Abysinia (now Ethiopia); the Battle of Britain (July-October 1940); North Africa (May 1941November 1942) - inter alia the Battle of Tobruk, El Alamein; landing operation on Madagascar (June 1942-November 1942); in the liberation of Italy (April 1943-May 1945) - inter alia Monte Cassino, Ancona, Florence and Rome, and on supply flights over Warsaw (August 1944-September 1944). The total number of South African soldiers participating in the Second World War was: the army - 132,194 the air force 44,569 , the navy $-9,457$, female units 24,975 , support services (non-white citizens of the Union) $123,131^{68}$.

The production of explosives began on a large scale (near Johannesburg there operated the largest plant of explosives in the world) and military equipment (e.g. guns, howitzers, armored vehicles). Some industries greatly expanded (e.g. steel, food, textile and paper), port infrastructure likewise. South Africa was on a strategic maritime route to transport troops, military equipment and raw materials. Tens of thousands of Allied soldiers arrived there with the aim of training, hospitalization, quarantine or leave. The state was also a place of detention for prisoners of war, mostly Italians.

In summary, at the outbreak of the Second World War, the Union of South Africa in addition to the military unpreparedness was divided politically. The division into the supporters and the opponents of the war with Germany was clear, both in the parliament as well as in the South African society. The Union was one of the few states in the world where so significant political support and public acceptance of the ideology of Adolf Hitler and the Third Reich (among a large part of the Afrikaners) was expressed. In the Parliament this option, which has significant influence, was close to declare at least the neutrality of the Union (although as a dominion of the British Union should unconditionally support the Great Britain and its side to enter the war). On the other hand, in the Afrikaner community, organized in part on the model of paramilitary units, the option enjoyed so much support that there was a real threat to destabilize the state in order to promote Nazi Germany. Nevertheless, in a relatively short time, the Union of South Africa was able to prepare its institutions, society and economy for military action. An important role in the consolidation of the political elite and society around the fight against the Germans on the side of the Allies was played by J. C. Smuts.

\section{BIBLIOGRAPHY}

Balicki J., Historia Burów. Geneza państwa apartheidu, Wrocław 1980.

Basson J.L., J.G. Strijdom. Sy politieke loopbaan van 1929 tot 1948, Pretoria 1980.

68 Ibid.; D.W. Krüger, The Making of a Nation..., pp. 199-225. 
'Boer War: 1899-1902' in History of South Africa, History World, at <http://www.historyworld.net/wrldhis/PlainTextHistories.asp?ParagraphID=oui\#ixzz3iOp9p5gd>.

Breitenbach J.J. (ed.), South Africa in the Modern World (1910-1970). A Contemporary History, Pietermaritzburg 1974.

Citino R., Germany and the Union of South Africa in the Nazi Period, New York 1991 (Contributions to the Study of World History, 27).

Crafford F.S., Jan Smuts. A Biography, New York 1943.

Crwys-Williams J., A Country at War, 1939-1945. The Mood of a Nation, Rivonia 1992 (South Africans at War, 10).

Die Transvaler, 6 November 1940.

Friedman B., Smuts. A Reappraisal, Johannesburg 1975.

Gąsowski A., RPA, Warszawa 2006 (Historia Państw Świata w XX Wieku).

'Gen. Smuts Becomes Prime Minister Today', The Cape Times, 5 September 1939.

Gordon R.G., Talbot C.J. (eds.), From Dias to Vorster. Source Material on South African History 1488-1975, Cape Town 1977.

'Grave Crisis in Union Cabinet', The Cape Argus, 4 September 1939.

Smuts J.C., Greater South Africa. Plans for a Better World; Speeches, Johannesburg 1940.

Grütter W., Zyl D.J. van, The Story of South Africa, Cape Town 1981.

Hancock W.K., Smuts. The Fields of Force 1919-1950, Cambridge 1968.

Hancock W.K., Poel J. van der (eds.), Selections from the Smuts Papers, Vol. 6, Cambridge 1973.

Heever Ch.M. van den, General J.B.M. Hertzog, Johannesburg 1946.

Hepple A., Political Leaders of the Twentieth Century. Verwoerd, Harmondsworth 1967 (Pelican Book, A913).

Herd N., 1922. The Revolt on the Rand, Johannesburg 1966.

Hirson B., Yours for the Union. Class and Community. Struggles in South Africa 1930-1947, Johannesburg 1989.

'Historic Sitting of Parliament', The Cape Times, 5 September 1939.

Horrel M., Legislation and Race Relations. A Summary of the Main South African Laws which Affect Race Relationships, Johannesburg 1971.

Idzik A., Czterdziestolecie 20-ego Putku Piechoty Ziemi Krakowskiej, 1919-1959, Londyn 1959. Ingham K., Jan Christiaan Smuts. The Conscience of a South African, London 1986.

Kraus R., Old Master. The Life of Jan Christian Smuts, New York 1944.

Krüger D.W., The Making of a Nation. A History of the Union of South Africa. 1910-1961, Johannesburg-London 1969.

Liebenberg J., 'Hertzog in Power, 1924-1939' in C.F.J. Muller (ed.), 500 Years. A History of South Africa, Pretoria 1988.

Liebenberg J., 'Smuts in Power, 1939-1948' in C.F.J. Muller (ed.), 500 Years. A History of South Africa, Pretoria 1988.

Louw L.H., The Communist Danger, Cape Town 1940 (Publications of the Enlightenment Service of the Reunited Nationalist Party, 5).

MacNab R., The Story of South Africa House. South Africa in Britain, the Changing Pattern, Johannesburg 1983. 
Malinowski M.J., Republika Potudniowej Afryki. Przemiany wewnętrzne i ich międzynarodowe uwarunkowania, Warszawa 1988.

Meiring P., Smuts the Patriot, Cape Town 1975.

Neame L.E., General Hertzog. Prime Minister of the Union of South Africa since 1924, London 1930.

Nurek M., Polska w polityce Wielkiej Brytanii w latach 1936-1941, Warszawa 1983.

'Pirow Can Say Nothing', The Sunday Times (Special Ed.), 3 September 1939.

'Pretoria Kalm', Die Vaderland (Spesiale Uitgaaf), 1 September 1939.

'Premier for Neutrality. Gen. Smuts's Challenge', The Cape Argus, 4 September 1939.

Le Roux J.H. van, Coetzer P.W., Marais A.H. (eds.), Generaal J.B.M. Hertzog. Sy strewe en stryd, Johannesburg 1987.

Scholtz G.D., Die Rebellie 1914-1915, Johannesburg 1942.

Smuts J.C. Jr., Jan Christian Smuts. A Biography, Cape Town 1952.

South Africa 1982. Official Yearbook of the Republic of South Africa, Cape Town 1983.

Stadler A.W., 'The Period 1939 to 1948' in T. Cameron, S.B. Spies (eds.), An Illustrated History of South Africa, Cape Town 1988.

Thom H.B., D.F. Malan, Kaapstadt 1980.

Thompson L.M., The Unification of South Africa 1902-1910, Oxford 1960.

Thorp W.L., Thorp H.E., 'The Annals of South Africa' in W.L.Thorp (ed.), The Business Annals, New York 1926, at <http://www.nber.org/chapters/c4650.pdf>.

Villiers L. de, Marais J., Wiehahn N. (eds.), Doing Business with South Africa, New Canaan 1984.

Raczyński E., W sojuszniczym Londynie. Dziennik ambasadora Edwarda Raczyńskiego 1939-1945, Londyn 1974.

Walker E.A., A History of Southern Africa, London 1959, 1965.

Williams B., Botha, Smuts and South Africa, London 1946 ("Teach Yourself History" Library).

Zukowski A., 'Afryka Południowa a Powstanie Warszawskie' in M.M. Drozdowski (ed.), Powstanie Warszawskie z perspektywy pótwiecza, Warszawa 1995.

Prof. Arkadiusz Żukowski, Ph.D - research worker and lecturer, political scientist, Africanist, Head of the Division of International Political Relations, Director of the Institute of Political Science, Warmia and Mazury University in Olsztyn, Vice-chairman of the Committee on Political Sciences of the Polish Academy of Sciences, Member of the Board of the Polish Africanist Society. 